\title{
An analysis of decision making strategies of Kocaeli region football referees
}

\author{
Sabit Selvi ${ }^{1}$, and Elif Karagün ${ }^{2 *}$ \\ ${ }^{1}$ Institute of Health Sciences, Kocaeli University, Kocaeli, Turkey \\ ${ }^{2}$ Recreation Department, Sports Science Faculty, Kocaeli Üniversity, Kocaeli, Turkey
}

\begin{abstract}
In this study, in a football competition, which is one of the most interesting sports encounters today, the state of the decision-making strategies of referees, who play an important role in terms of final scores, is investigated. In line with this aim, efforts have been made to determine the decision-making strategies of Kocaeli football referees. Whether the decision-making strategies determined have changed according to variables such as gender, age, marital status, educational status, economic income, work done outside of refereeing, professional experience and refereeing years. For this purpose, "Decision Strategies Scale and Personal Information Form" developed by Bacanlı and Kuzgun [1], have been applied to a total of 117 football referees, 11 female and 106 male active football referees in Kocaeli. The results obtained from the scale applications were evaluated in the SPSS 21.00 statistical package program. As a result of the analyzes made; Subscales of decision-making strategies of referees are not significant in terms of gender, marital status, education, work experience, work done outside refereering, refereeing years; while it is not meaningful in terms of unstable, logical and dependent decision making sub-scales when compared to the economic level, it has been seen that only internal tepic decision making increases significantly when economic level is lower.
\end{abstract}

Keywords: Football, referee, decision making, decision strategy.

\section{Introduction}

Every human being begins to shape his/her life by constantly making decisions until the later periods of his life from the moment his/her mental ability develops. He gets experience and matures with difficulties or conveniences that he/she has encountered in his life after his decisions. Today's technology has an intense flow of information. The individual in this fast flow is constantly faced with changing circumstances, difficulties and sometimes problems and the individual must cope with these problems quickly. In order to cope quickly and healthily with problems, the individual must produce logical and correct

\footnotetext{
* Corresponding author: elif.karagun@gmail.com
} 
solutions. Decision-making has been described as an orientation that will solve the problem when there is a need and many alternatives that can achieve a goal [2]. It is defined as "a cognitive process" and the selection of the most favorable solution from the existing options for eliminating any need and meeting this need [3]. When any issue or problem is encountered; it is stated that people use different strategies in order to be able to make a decision and it is the process of knowing how people will behave when a situation should be decided [4]. Decision making, considered as a cognitive state and considered as one of the important functions in an individual's life, has been defined as choosing the most appropriate alternative for problem solving or solution when it is deemed necessary in any matter $[3,5,6]$. It has been stated that the individual will be directed to the alternative that is thought to solve the problem considering the fact that there many alternatives when a decision is made, and a decision is also made to adapt and different strategies will be used in these processes $[4,7]$. It has also been reported that cognitive processes that are away from the anxiety and comfort are necessary to provide solutions and make the right decisions [8].

It has been reported that the decisions that are seen as one of the basic skills in a person's life will lead to positive changes in order to bring solutions in human life when given in a healthy way that will lead to correct, timely, correct and appropriate solutions, and wrong decisions will adversely affect life in on the contrary [9]. Researchers working on decision making and putting forward ideas on this issue; defined effective decisionmaking as "a multifaceted process" involving informed decision-making by individuals who discern the contradiction between the current situation and the situation they are aiming at, testing various alternatives to reduce this contradiction and evaluating the results after these tests, storing information processing and feedback on the effectiveness of the tested cases " [10].

It has been reported that people who are actively involved in this process also perform the probability calculations of events and eliminate and select between two or more options [11].

Referees are defined as the officials who are in the field of competition to manage competitions or games in the most equitable manner by observing the rights of the teams competing against each other, applying the rules of the game in an impartial manner [7].

It was stated that while the success in the sports environment was determined during the competition, it was evaluated within the framework of the rules of the game played. It is explained that the referees are responsible for the execution of the competition, considering the suitability of a game with the rules and the rights of the competing teams. We often witness the decisions of the referees are discussed after the competition on the media and press. While the referees, who play an important role in contests in sports environments, play a supervisory role in complying with the rules, on the other hand, when it is considered that the referees have a decision-making role, the definition of the decision-making, and that it is the selection and elimination of an option among many more options, and that we often see commentaries on the press after the competition that the referees have made incorrect decisions in the game, it was wondered how the decision-making strategies of referees are. In this respect, the decision-making strategies of football referees in the football field, which is of particular interest to the masses, were searched and the answers were asked whether these strategies changed according to gender, age, marital status, educational status, economic income, work done outside of refereeing, professional experience and refereeing years.

This research was carried out in order to determine what strategies the football referees followed while deciding and how the decision strategies differ according to the variables. 


\section{Materials and methods}

This research is a descriptive study. After receiving permission to conduct a survey for the research in 2016 from the Kocaeli Provincial Arbitration Board and the Central Referee Board, participants were informed about the research during the referee training seminars held at the Kocaeli International Youth Center and scales were distributed to those who voluntarily participated in the research. A total of 117 football referees actively working in Kocaeli province, including 106 males and 11 females, who were regarded valid after the scale applications, were included in the study.

\subsection{Data collection tools}

In the light of literature information; Likert type "Decision Strategies Scale" (DSS) consisting of 40 items and 4 subscales developed by Bacanlı and Kuzgun [1], was used to determine decision strategies with the "Information Form" formed by the researchers to determine the socio-demographic characteristics of the referees.

Four sub-scales of these decision strategies are:

1.Impulsive behavior: acting extemporaneously without giving proper thought to options,

2.Logical-Systematic Behavior: Rational decision making; Information about options,

3.Dependency: Taking decisions continuously by asking others,

4.Chaging decisions very often

The lowest score that can be taken from each subscale is 10 and the highest score is 40 . The increase in scores from the subscales indicates that the participant adopts the decisionmaking style for that subscale.

\subsection{Statistical data analysis}

The collected data were analyzed with the SPSS 21.00 package program. The normal distribution of the data was determined by the Kolmogorov Smirnov test. Parametric tests were used because the sample showed normal distribution. T test was performed in binary comparisons and one-way analysis of variance (ANOVA) in multiple groups to determine the source of the difference between the groups. The error level for the significance of the statistics was accepted as $\mathrm{p}<0.05$.

\section{Results}

In this section, the analysis results of decision making strategies of football referees according to the demographic variables such as gender, marital status, age, economic status, level of education, work outside refereeing, refereeing years, professional experience, and score averages of the sub-dimensions of the decision-making scale were included.

Table 1. Average points taken from decision-making subscales

\begin{tabular}{|c|c|c|c|c|}
\hline $\begin{array}{c}\text { Decision Making } \\
\text { Subscales Score } \\
\text { Averages }\end{array}$ & $\begin{array}{c}\text { Impulsive } \\
\text { behavior } \\
\text { mean } \pm \text { Sd }\end{array}$ & $\begin{array}{c}\text { Indecisive } \\
\text { mean } \pm \text { Sd }\end{array}$ & $\begin{array}{c}\text { Dependant } \\
\text { decision- } \\
\text { making } \\
\text { mean } \pm \text { Sd }\end{array}$ & $\begin{array}{c}\text { Logical } \\
\text { decision- } \\
\text { making } \\
\text { mean } \pm \text { Sd }\end{array}$ \\
\hline & $22.37 \pm 3.81$ & $19.95 \pm 4.27$ & $21.71 \pm 3,08$ & $27.52 \pm 4.11$ \\
\hline
\end{tabular}


The mean of the subscales of decision-making strategies of referees from the findings: the mean of the scores obtained from the logical-systematic decision making subscale is $\mathrm{X}$ $=27.52 \pm 4.10$. The average of the subscale scores of the impulsive decision making strategy is $X=22.37+3.81$. The dependent decision making strategy subscale point average is $X=23,90 \pm 3,21$ and the indecisive decision subscale point average is $X=19,95$ $\pm 4,27$. Based on the obtained data, it was found that the mean of the subscale scores and standard deviation values were the highest of the mean of the logical / systematic decision subscale and the lowest of the indecisive subscale.

The general decision-making strategies of the referees vary between 78 and 121, with an average of 93.38 points. It was determined that the referees had a decision strategy in the middle level.

Table 2. Percentage values of participants based on socio-demographic characteristics

\begin{tabular}{|c|c|c|c|}
\hline \multicolumn{2}{|c|}{ Variables } & $\mathbf{N}$ & $\%$ \\
\hline \multirow[t]{2}{*}{ Gender } & Female & 11 & 9,4 \\
\hline & Male & 106 & 90,6 \\
\hline \multirow{6}{*}{ Age } & $15-19$ & 14 & 12 \\
\hline & $20-24$ & 45 & 38,4 \\
\hline & $25-29$ & 31 & 26,5 \\
\hline & 30-34 & 22 & 18,8 \\
\hline & $35-39$ & 3 & 2,6 \\
\hline & 39 and over & 2 & 1,7 \\
\hline \multirow{3}{*}{ Educational level } & High school & 33 & 28,2 \\
\hline & University & 75 & 64,1 \\
\hline & Postgraduate & 9 & 7,7 \\
\hline \multirow[b]{2}{*}{ Marital Status } & Married & 33 & 28,2 \\
\hline & Single & 84 & 71,8 \\
\hline \multirow{4}{*}{ Income Level } & 0-800 TL & 33 & 28,2 \\
\hline & 801-1500 TL & 16 & 13,7 \\
\hline & $1501-2500 \mathrm{TL}$ & 30 & 25,6 \\
\hline & $2501 \mathrm{Tl}$ and above & 38 & 32,5 \\
\hline \multirow{4}{*}{ Work experience } & 0-5 years & 84 & 71,8 \\
\hline & 6-10 years & 21 & 17,9 \\
\hline & 11-15 years & 8 & 6,9 \\
\hline & 16-20 years & 4 & 3,4 \\
\hline \multirow[b]{2}{*}{ Work } & Private sektor & 90 & 76,9 \\
\hline & Public sektor & 27 & 23,1 \\
\hline \multirow{4}{*}{ Refereering years } & 1-4 years & 64 & 54,7 \\
\hline & 5-8 years & 26 & 22,2 \\
\hline & 9-12 years & 17 & 14,5 \\
\hline & 13 years and above & 10 & 8,6 \\
\hline
\end{tabular}

When the socio-demographic distributions of the referees included in Table 2 are examined, it is seen that the majority (90.6) of the referees are male, 20-24 years of age (38.4\%), the unemployed is $71.8 \%$, the incomes are $32.5 \% 71.8 \%$ of the work experience is between $0-5$ years, $76.9 \%$ of them are working in the private sector and $54.7 \%$ of them have 1-4 years of refereeing experience. 
Table 3. Results of variance analysis (ANOVA) of mean values of decision making subscales of the referees participated in the research

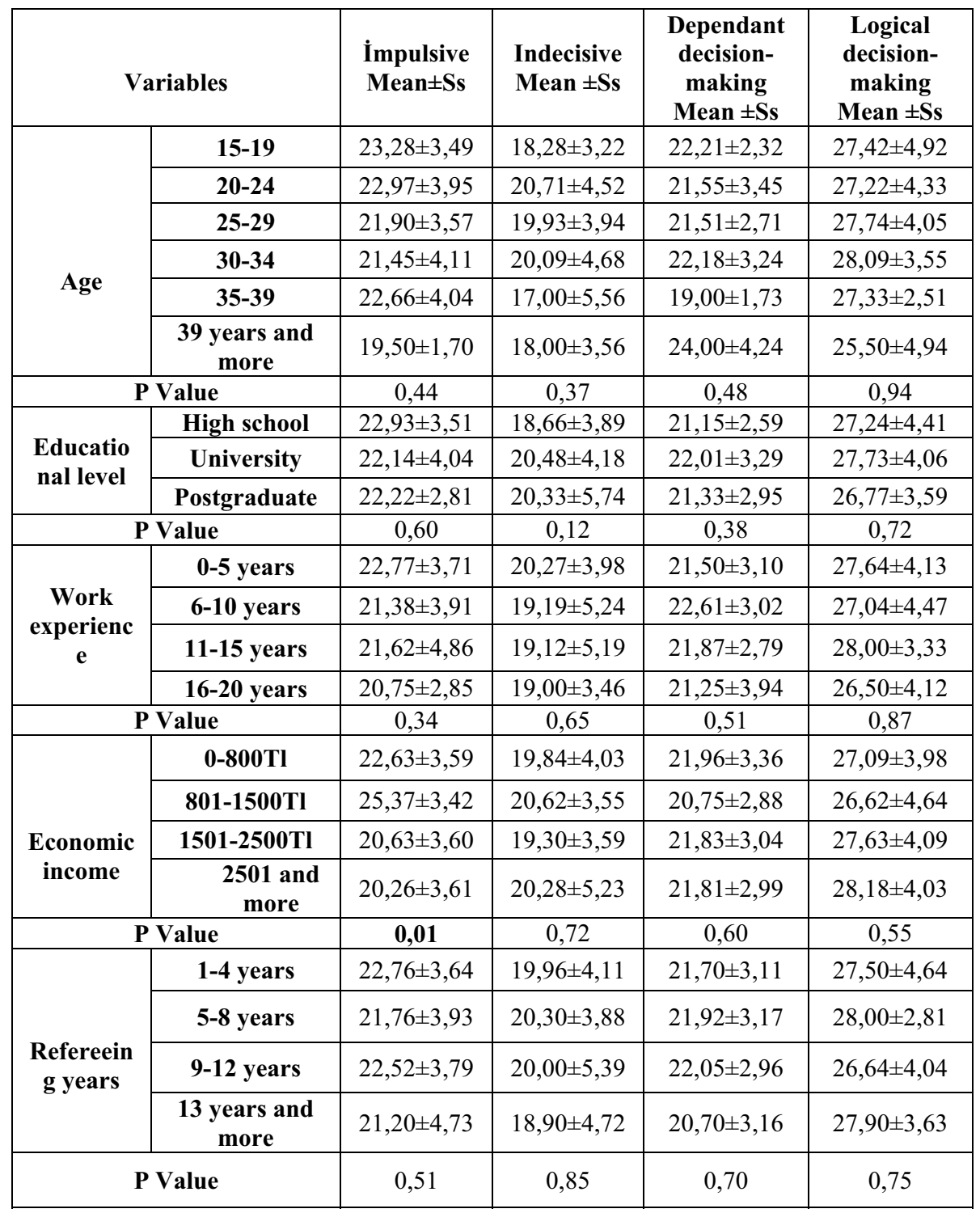

Subscales of decision making strategies of the referees participating in the research group; statistical values of the ANOVA test related to variables such as age, educational status, work outside of refereeing, economic income and refereeing years were not found statistically significant as shown in Table $3(\mathrm{p}>0,05)$. Only the results of the impulsive decision making subscale were significant according to the economic situation variable $(\mathrm{p}=$ $\mathbf{0 , 0 1}, \mathrm{p}<\mathbf{0 , 0 5}$ ). As income rises, meaningful results are found in connection with the increase in the impulsive decision. 
Table 4. Results of the t-test on the mean values of the decision making subscales of the referees participated in the survey

\begin{tabular}{|c|c|c|c|c|c|}
\hline \multicolumn{2}{|c|}{ Variables } & $\begin{array}{c}\text { Impulsive } \\
\text { Mean } \pm \text { Ss }\end{array}$ & $\begin{array}{c}\text { Indecisive } \\
\text { Mean } \pm \text { Ss }\end{array}$ & $\begin{array}{c}\text { Dependant } \\
\text { decision- } \\
\text { making } \\
\text { Mean } \pm \text { Ss }\end{array}$ & $\begin{array}{c}\text { Logical } \\
\text { decision- } \\
\text { making } \\
\text { Mean } \pm \text { Ss }\end{array}$ \\
\hline \multirow{2}{*}{ Gender } & Female & $23,36 \pm 2,83$ & $20,45 \pm 5,08$ & $22,63 \pm 3,44$ & $26,36 \pm 4,05$ \\
\cline { 2 - 7 } & Male & $22,27 \pm 3,89$ & $19,90 \pm 4,21$ & $21,62 \pm 3,05$ & $27,64 \pm 4,11$ \\
\hline \multicolumn{2}{|c|}{ P Value } & 0,36 & 0,68 & 0,30 & 0,32 \\
\hline \multirow{2}{*}{$\begin{array}{c}\text { Marital } \\
\text { Status }\end{array}$} & Married & $21,81 \pm 4,10$ & $19,66 \pm 4,81$ & $22,51 \pm 2,69$ & $27,30 \pm 4,17$ \\
\cline { 2 - 7 } & Single & $22,59 \pm 3,69$ & $20,07 \pm 4,07$ & $21,40 \pm 3,18$ & $27,60 \pm 4,10$ \\
\hline \multicolumn{2}{|c|}{ P Value } & 0,32 & 0,32 & 0,08 & 0,72 \\
\hline \multirow{2}{*}{ Work } & $\begin{array}{c}\text { Private } \\
\text { Sector }\end{array}$ & $22,30 \pm 3,11$ & $19,96 \pm 3,66$ & $21,77 \pm 3,11$ & $27,33 \pm 3,98$ \\
\cline { 2 - 7 } & $\begin{array}{l}\text { Public } \\
\text { Sector }\end{array}$ & $22,62 \pm 3,69$ & $19,92 \pm 5,97$ & $21,51 \pm 3,03$ & $28,14 \pm 4,53$ \\
\hline \multicolumn{2}{|c|}{ P Value } & 0,69 & 0,64 & 0,70 & 0,36 \\
\hline
\end{tabular}

When Table 4 is examined, no significant difference was found in any of the subscales of logical-systematic decision making, impulsive decision making, dependent decision making, and indecisive decision making according to the variables gender, marital status and and work done outside refereeing in public or private sector $(p>0,05)$.

\section{Discussion}

When we evaluate the results of our work in terms of gender; Internal impulsive, logical, dependent and indecisive decision making subscale scores did not show a significant difference even though they were high in favor of women. In our study, the reason why there is no gender difference in decision-making strategies in male and female referees is that judges should only make judgments on the basis of rules, not on their own emotional states and it is thought that decision-making scale results do not make a difference in terms of gender, as referees make decisions on basis of the rules of the sport branch they arbitrate. When other studies in the literature are examined, there are studies reporting that there is no difference in terms of gender in support of our work [12, 13], and there are also studies that suggest that girls use logic-systematic and dependant and decision-making strategies more than men, and that men use the impulsive decision strategy more than girls [2]. Likewise, some studies have found that girls use impulsive [14], some use logical [15], and others use dependent decision making strategy [16] more than men. Even if a generalization can not be made from the outcomes, it can be said that there is a need for further research to analyze the difference between the decision strategies and the gender and the situation regarding this difference in detail.

It has been seen that decision-making styles are independent of each other but not completely different from one another, and that individuals do not use a single style when making important decisions, instead they use all these styles [17]. In a study, it was seen that although there was no significant difference according to gender, women were more likely to use rational decision-making style than men and males used more dependent decision-making styles compared to females [18].

According to the marital status of the referees in our research, there was no significant difference in the logical-systematic decision making, the impulsive decision making, the 
dependent decision making, and the indecisive decision making subscales. There is no study in the literature on the variable of marital status.

There was no significant difference in decision making subscales according to age variable $(\mathrm{P}>0.05)$. According to other research results comparing adult and adolescent decision making processes, age and gender have not been effective in making final decisions $[13,18,19]$. This finding is also parallel to the results of our research. While in some studies, it was found that only dependent decision making style showed significant difference according to age [20]. Some studies have shown that managers in the age range of 36-40 years compared those in the 25-30 age range, and managers in the age range of 4145 compared to those 20-25 are more rationally examining options in the decision making process $[13,18,21]$. Considering these results, it can be considered that as the age progresses, there is an increase in the experience and logical evaluation, and a healthier decision is made.

There was no significant difference in decision-making subscales, if we were to interpret our findings according to educational status variable. When we look at the literature, while some of the studies support our findings $[18,22]$, some studies have also found that the rational, spontaneous-momentary, dependant, and avoidance decision style averages do not vary significantly relative to their level of education, but that the heuristic decision averages are significantly different as education level increases but there is no difference in other areas [7].

In the study we conducted, there was no significant difference in all the subscales related to decision making based on the work done outside refereeing, and the year of refereeing, ie work experience. It has been stated that being experienced at work is not effective in decisions [7, 22]. In addition to the literature findings supporting our research results [7], it has been stated that managers who have 21-25 years of compared to those who have 20 years of experience have evaluated the options more carefully and evaluated pluses and minuses considering every possibility [21]

There was no significant difference in decision making subscales according to economic income variable. However, there was a significant difference in favor of those who had low incomes only in the impulsive decision making subscale. In a study conducted in the light of literature; It has been determined that the instant decision making strategy is different according to income level, the instant decision making style of low income individuals is higher than other income groups, and the other decision making styles do not show any difference [7].

\section{References}

1. Y. Kuzgun, F. Bacanli, PDR'de Kullanılan Ölçekler. Ankara, Nobel Yayın Dağıtım, (2005)

2. Y. Kuzgun, Karar Stratejileri Ölçeği: Geliştirilmesi ve Standardizasyonu. VII. Ulusal Psikoloji Kongresi Bilimsel Çalışmaları. Ankara, Türk Psikologlar Derneği, 161-170. (1992)

3. S.S. Güçray, Bazı Kişisel Değişkenler, Algılanan Sosyal Destek ve Atılganlığın Karar Verme Sitilleri İle İlişkisi. Türk Psikolojik Danışma ve Rehberlik Dergisi, 2.9, 7-16. (1998)

4. H. Ö. Ersever, Karar Verme Becerileri Kazandırma Programının ve Etkileşim Grubu Deneyiminin Üniversite Öğrencilerinin Karar Verme Stilleri Üzerindeki Etkileri. Unpublished doctoral thesis, Ankara Üniversitesi, Ankara Üniversitesi Sosyal Bilimler Enstitüsü, Ankara, (1996)

5. A. Dağlı, Problem çözme ve karar verme. Elektronik Sosyal Bilimler Dergisi, 3(7), 41-49, (2004) 
6. J. Noone, Concept Analysis of Decision Making. Nursing Forum, 37 (3), 21 - 32. (2002)

7. Ö. A. Tekin, Yönetimde karar verme: Batı Antalya bölgesinde bulunan beş yıldızlı otel işletmelerindeki çeşitli departman yöneticilerinin karar verme stillerini tespit etmeye yönelik uygulamalı bir araştırma, Unpublished master's thesis, Akdeniz Üniversitesi Sosyal Bilimler Enstitüsü Turizm İşletmeciliği ve Otelcilik Anabilim Dalı, Antalya. (2009)

8. J. Eldeleklioğlu, Karar Stratejileri ile Ana Baba Tutumları Arasındaki İliski. Unpublished doctoral thesis, Gazi Üniversitesi, Sosyal Bilimler Enstitüsü, Ankara. (1996)

9. K. Tatlılığlu, Üniversite Öğrencilerinin Karar Vermede Öz-Saygı Düzeyleri ile Karar Verme Stilleri Arasındaki İlişkinin Bazı Değişkenlere Göre İncelenmesi.”, Akademik Sosyal Araştırmalar Dergisi, 2 (1), 150-170. (2014)

10. F. Korkut, "Lise Öğrencilerinin Problem Çözme Becerileri”, Hacettepe Üniversitesi Eğitim Fakültesi Dergisi, 22, 177 - 184. (2002)

11. S. Budak, Psikoloji Sözlüğü, Ankara, Bilim ve Sanat Yayınları. (2000)

12. O. Çolakkadioğlu, Çatişma kuramina dayali olarak geliştirilen karar verme beceri eğitimi grup uygulamalarinin ergenlerin karar verme stillerine etkisi, Unpublished master's thesis, Çukurova Üniversitesi, Sosyal Bilimler Enstitüsü, Eğitim Bilimleri Anabilim Dalı, Adana. (2010)

13. A. M. Hulderman, Decision-Making Styles and Learning Strategies of Police Officers: Implications for Community Policing. Doctorate Thesis, Oklahoma State University, Faculty of the Graduate College of the Oklahoma State University, Oklahoma. (2003)

14. M. G. Tiryaki, Üniversite öğrencilerinin karar verme davranışlarının bazı değişkenler açısından incelenmesi. Unpublished master's thesis, Hacettepe Üniversitesi Sosyal Bilimler Enstitüsü. (1997)

15. S. Kesici, Üniversite öğrencilerinin karar verme stratejilerinin psikolojik ihtiyaç örüntüleri ve özlük niteliklerine göre karşılaştırmalı olarak incelenmesi. Unpublished doctoral thesis, Konya: Selçuk Üniversitesi Sosyal Bilimler Enstitüsü. (2002)

16. W. Mau, Cultural differences in career decision-making styles and self efficacy. Journal of Vocational Behavior, 57, 365-378. (2000)

17. P. Thunholm, Decision-Making Scale: Habit, Style or Both?, Personality and Individual Differences, 36, 931 - 944. (2004)

18. R. P. Sanders, The Decision-Making Styles, Ways of Knowing, and Learning Strategy Preferences of Clients At a One-Stop Career Center. Doctorate Thesis, Southern Oklahoma State University, Faculty of the Graduate College of the Oklahoma State University, Stillwater, Oklahoma. (2008)

19. A.K. Ganzel, Adolescent decision making: The influence of mood, age, and gender on the consideration of information [Electronic version]. Journal of Adolescent Research, 14, 289-318 (1999)

20. A. Arın, Lise yöneticilerinin öğretim liderliği davranışları ile kullandıkları karar verme stratejileri ve problem çözme becerileri arasındaki ilişki düzeyi. Unpublished master's thesis, Eskişehir Osmangazi Üniversitesi, Sosyal Bilimler Enstitüsü, Eğitim Bilimleri Anabilim Dalı, Eskişehir. (2006)

21. K. Özcan, Yöneticilerde Karar Verme ile Kaygı İlişkileri. Unpublished master's thesis, Marmara Üniversitesi, Sosyal Bilimler Enstitüsü, Teknoloji Eğitimi Anabilim Dal, İstanbul, (1999)

22. H. P. Kao, Taiwanese Executive's Leadership Styles and Their Preffered DecisionMaking Models Used in Mainland China. Doctorate Thesis, The University of the Incarnate Word, The School of the Graduate Studies of The University of the Incarnate Word, Texas. (2005) 